NASA/TM-2005-213819

Development of Parametric Mass and Volume Models for an Aerospace SOFC/Gas Turbine Hybrid System

Robert Tornabene, Xiao-yen Wang, Christopher J. Steffen, Jr., and Joshua E. Freeh

Glenn Research Center, Cleveland, Ohio 
Since its founding, NASA has been dedicated to the advancement of aeronautics and space science. The NASA Scientific and Technical Information (STI) Program Office plays a key part in helping NASA maintain this important role.

The NASA STI Program Office is operated by Langley Research Center, the Lead Center for NASA's scientific and technical information. The NASA STI Program Office provides access to the NASA STI Database, the largest collection of aeronautical and space science STI in the world. The Program Office is also NASA's institutional mechanism for disseminating the results of its research and development activities. These results are published by NASA in the NASA STI Report Series, which includes the following report types:

- TECHNICAL PUBLICATION. Reports of completed research or a major significant phase of research that present the results of NASA programs and include extensive data or theoretical analysis. Includes compilations of significant scientific and technical data and information deemed to be of continuing reference value. NASA's counterpart of peerreviewed formal professional papers but has less stringent limitations on manuscript length and extent of graphic presentations.

- TECHNICAL MEMORANDUM. Scientific and technical findings that are preliminary or of specialized interest, e.g., quick release reports, working papers, and bibliographies that contain minimal annotation. Does not contain extensive analysis.

- CONTRACTOR REPORT. Scientific and technical findings by NASA-sponsored contractors and grantees.
- CONFERENCE PUBLICATION. Collected papers from scientific and technical conferences, symposia, seminars, or other meetings sponsored or cosponsored by NASA.

- SPECIAL PUBLICATION. Scientific, technical, or historical information from NASA programs, projects, and missions, often concerned with subjects having substantial public interest.

- TECHNICAL TRANSLATION. Englishlanguage translations of foreign scientific and technical material pertinent to NASA's mission.

Specialized services that complement the STI Program Office's diverse offerings include creating custom thesauri, building customized databases, organizing and publishing research results ... even providing videos.

For more information about the NASA STI Program Office, see the following:

- Access the NASA STI Program Home Page at http://www.sti.nasa.gov

- E-mail your question via the Internet to help@sti.nasa.gov

- Fax your question to the NASA Access Help Desk at 301-621-0134

- Telephone the NASA Access Help Desk at 301-621-0390

- Write to:

NASA Access Help Desk

NASA Center for AeroSpace Information 7121 Standard Drive

Hanover, MD 21076 
NASA/TM-2005-213819

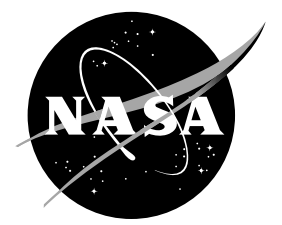

\section{Development of Parametric Mass and Volume Models for an Aerospace SOFC/Gas Turbine Hybrid System}

Robert Tornabene, Xiao-yen Wang, Christopher J. Steffen, Jr., and Joshua E. Freeh

Glenn Research Center, Cleveland, Ohio

Prepared for the

Turbo Expo 2005

sponsored by the American Society of Mechanical Engineers

Reno, Nevada, June 6-9, 2005

National Aeronautics and

Space Administration

Glenn Research Center 


\section{Acknowledgments}

The authors gratefully acknowledge the support of Robert R. Tacina and Thomas M. Tomsik, NASA Glenn; Chia (Judy) H. Yen, UNT; Louis M. Larosiliere, GE Gas Turbines, LLC; Thomas L. Cable and Stephen W. Sofie, QSS Group, Inc.; and Chip Redding, NASA Glenn, during this program development.

This work was sponsored by the Low Emissions Alternative

Power Project of the Vehicle Systems Program at the NASA Glenn Research Center.

Available from

NASA Center for Aerospace Information 7121 Standard Drive

Hanover, MD 21076
National Technical Information Service 5285 Port Royal Road Springfield, VA 22100 


\title{
Development of Parametric Mass and Volume Models for an Aerospace SOFC/GAS Turbine Hybrid System
}

\author{
Robert Tornabene, Xiao-yen Wang, Christopher J. Steffen, Jr., and Joshua E. Freeh \\ National Aeronautics and Space Administration \\ Glenn Research Center \\ Cleveland, Ohio 44135
}

\begin{abstract}
In aerospace power systems, mass and volume are key considerations to produce a viable design. The utilization of fuel cells is being studied for a commercial aircraft electrical power unit. Based on preliminary analyses [1, 2], a SOFC/gas turbine system may be a potential solution. This paper describes the parametric mass and volume models that are used to assess an aerospace hybrid system design.

The design tool utilizes input from the thermodynamic system model and produces component sizing, performance and mass estimates. The software is designed such that the thermodynamic model is linked to the mass and volume model to provide immediate feedback during the design process. It allows for automating an optimization process that accounts for mass and volume in its figure of merit. Each component in the system is modeled with a combination of theoretical and empirical approaches. A description of the assumptions and design analyses is presented.
\end{abstract}

\section{INTRODUCTION}

A spreadsheet program has been developed to provide preliminary mass and performance estimates of the various components that would be required in an Aircraft Fuel Cell Power System (AFCPS) for an aircraft auxiliary power unit (APU). The program reads in the thermodynamic system model data and provides preliminary component mass and performance estimates so that the mass impact of the hybrid fuel cell system modifications can be quickly ascertained. This allows for rapid parametric trade studies to be performed to optimize the development of an aircraft fuel cell power system.

The objective of this effort is to provide a tool for parametric investigations that can produce mass and volume estimates of major components in the SOFC/APU system that can then be used to trade system performance with mass and volume. By replacing turbine APU's, hybrid fuel cell systems may dramatically reduce NOx emissions. The fuel cell system will provide increased power output at altitude and should also be lower in initial cost. It is anticipated that the increased fuel efficiency will be more than offset by the increase in the fuel cell system mass, by reducing the amount of fuel to be carried. The power range being examined is $440 \mathrm{~kW}$ [1].

The baseline configuration for the spreadsheet program development is based on the utilization of a catalytic partial oxidation (CPOX) fuel reformer in the AFCPS. The APU installation scheme considered for this investigation utilizes pressurized air flow at $75.2 \mathrm{kPa}$ and $20^{\circ} \mathrm{C}$ (for the aircraft cruise condition case) from the aircraft cabin for the compressor inlet feed flow. The components in the hybrid fuel cell/gas turbine system are designed based on projected 2015 technology. The system components modeled include a centrifugal compressor, fuel pump, water pump, CPOX fuel reformer, heat exchanger, steam generator, solid oxide fuel cell, combustor, starter/generator, radial inflow turbine and associated interconnecting piping. A schematic of the baseline aircraft fuel cell power system is shown in Figure 1. A preliminary three dimensional solid model of all of the components for the hybrid SOFC/gas turbine system packaged within a Boeing 777 tail section system is presented in Figure 2. Overall APU system requirements are derived from [3]. An initial discussion of component design features is presented followed by a demonstration of component sizing at various operating conditions. Two examples of system mass and volume estimates for a SOFC/hybrid system at distinct operating conditions are also provided. 
NOMENCLATURE

\begin{tabular}{|c|c|c|}
\hline Symbol & Units & Description \\
\hline $\mathrm{C}_{\mathrm{P}}$ & $\left.\overline{\mathrm{kJ} /(\mathrm{kg}}-{ }^{\circ} \mathrm{C}\right)$ & Gas specific heat \\
\hline $\mathrm{C}_{\mathrm{X} 1} / \mathrm{u}_{2}$ & & $\begin{array}{l}\text { Impeller inlet velocity to discharge } \\
\text { peripheral speed ratio }\end{array}$ \\
\hline Lpass & $\mathrm{cm}$ & Length of steam generator tube passes \\
\hline NW & & Number of steam generator tube passes \\
\hline Ns & & Compressor specific speed \\
\hline $\mathrm{R}_{\mathrm{h} 1}$ & meter & Impeller inlet hub radius \\
\hline SL & $\mathrm{cm}$ & Steam generator tube spacing \\
\hline $\mathrm{T}$ & ${ }^{\circ} \mathrm{C}$ & Gas temperature \\
\hline $\mathrm{Zc}$ & & No. of compressor blades/splitters \\
\hline $\mathrm{Zt}$ & & Number of turbine rotor blades \\
\hline $\mathrm{k}$ & $\mathrm{W} /\left(\mathrm{m}^{-}{ }^{\circ} \mathrm{C}\right)$ & Gas thermal conductivity \\
\hline$\alpha_{\mathrm{C} 1}$ & degrees & Turbine nozzle exit flow angle \\
\hline$\alpha_{\mathrm{C} 2}$ & degrees & $\begin{array}{l}\text { Compressor blade exit absolute flow } \\
\text { angle }\end{array}$ \\
\hline$\beta_{1}$ & degrees & Turbine rotor blade inlet flow angle \\
\hline$\beta_{2}$ & degrees & $\begin{array}{l}\text { Compressor blade exit sweepback } \\
\text { angle }\end{array}$ \\
\hline$\Delta$ & & $\begin{array}{l}\text { Turbine rotor hub/shroud diameter ratio } \\
\text { at the exducer exit }\end{array}$ \\
\hline$\eta_{\mathrm{P}, \mathrm{e}}$ & & Turbine rotor polytropic efficiency \\
\hline$\mu$ & $\mathrm{kg} /(\mathrm{m}-\mathrm{sec})$ & Gas dynamic viscosity \\
\hline$\rho$ & $\mathrm{kg} / \mathrm{m}^{3}$ & Gas density \\
\hline
\end{tabular}

\section{MODEL DEVELOPMENT, DESIGN, PERFORMANCE AND MASS ESTIMATE}

Design and performance models of the various components in the SOFC/APU system were generated in order to provide an accurate mass estimate. These models consisted of separate component analyses that included geometrical considerations and state variables (and their effect on individual component performance) and their impact on the mass and volume of each individual component. Components modeled include a solid oxide fuel cell, a combustor exhaust to air heat exchanger, a steam generator, a compressor, a turbine, a fuel reformer, a combustor, fuel and water pumps (and associated electric motors to drive them), a hot component containment vessel (hot box) and associated interconnecting piping. A separate spreadsheet was generated for each component and these spreadsheets were linked (as applicable) to perform an entire system mass and volume analysis based on specified system performance.

A Visual Basic macro is incorporated into the program to alleviate the problem of the user having to resolve the iterative routines in various worksheets in order to obtain an updated design. This macro allows for faster turnaround during parametric studies.

For this preliminary study, minimal structural stress analysis at the system level was performed (component mounting, bulkhead attachments, vibration effects, etc.). However, preliminary stress and heat transfer analyses on the component containment vessels were performed. Since the tail section is vented to ambient, the SOFC/APU system needs to be able to withstand low ambient temperature and pressure conditions that exist at altitude. Therefore, in order to reduce thermal losses, external insulation of hot components will be required.
Each individual component worksheet calculation is internally documented to the fullest extent possible to allow for future modifications and enhancements. A description of the design calculations and assumptions used to predict the performance and mass of each component in the SOFC system is described in the following sections.

\section{Compressor}

The centrifugal compressor in the system takes cabin air at the inlet and pressurizes it to supply high pressure air to the cathode side of the solid oxide fuel cell and the fuel reformer. Prior to entering these devices, the high pressure air is split, with the fuel cell air heated through a heat exchanger and the unheated air routed to the fuel reformer. The compressor worksheet utilizes the system inlet and discharge flow rates, temperatures and pressure data and determines the required compressor pressure ratio based on the discharge pressure specified. A preliminary centrifugal impeller design is completed based on a design method described in [4].

For optimum efficiency, the centrifugal compressor specific speed, Ns $=0.8$ is fixed. The compressor rotational speed is then calculated based on the specific speed and the required mass flow rate and pressure ratio. Compressor design specifications and assumptions for the compressor blading are summarized in Table 1. These parameters allow for development of the inlet and discharge velocity diagrams. The exit velocity diagram for the centrifugal compressor is shown in Figure 3.

Once the impeller inlet hub radius, shroud radius and exit diameter are calculated, the meridional blade shape is determined. To obtain the meridional blade shape, the shroud shape is assumed to be $1 / 4$ of a circle and the hub shape is assumed to be $1 / 4$ of an ellipse. The impeller mass is determined by calculating incremental volumes of the hub and blades based on the volume of a frustum of a cone. A blade solidity of $20 \%$ is assumed to estimate the amount of metal in the blade area. The total impeller mass is calculated based on the density of stainless steel and the volume estimate. The centrifugal impeller design method is described in detail in [4]. The compressor diffuser and housing mass estimate is based on a method developed by the Garrett Turbine Engine Company described in [5]. Table 1 summarizes the assumptions made in the centrifugal compressor design and mass estimate.

Table 1 - Summary of assumptions used for the centrifugal compressor impeller design and mass estimate

Compressor specific speed, Ns

Number of Blades/Splitters, Zc

0.8

Blade Exit Sweepback Angle, $\beta_{2}$

Blade Exit Absolute Flow Angle, $\alpha_{\mathrm{C} 2}$

Impeller Inlet Velocity to Discharge

Peripheral Speed Ratio, $\mathrm{C}_{\mathrm{x} 1} / \mathrm{u}_{2}$

Impeller Inlet Hub Radius, $\mathrm{R}_{\mathrm{h} 1}$

Hub Thickness Behind Blades

Shroud Shape

Hub Shape

Blade Solidity
$2.5 \mathrm{~cm}$

$0.19 \mathrm{~cm}$

$1 / 4$ of a circle

$1 / 4$ of an ellipse

$20 \%$ 


\section{Heat Exchanger}

A compact heat exchanger design was performed in an attempt to minimize the heat exchanger volume and mass based on performance requirements provided by the system analysis. The purpose of this heat exchanger is to provide heated air to the solid oxide fuel cell. The heat exchanger inlet process air is fed from the compressor discharge. Heat is added to the air from the exhaust gas exiting from the combustor.

The combustion air to process air compact heat exchanger was designed based on methods described in [6]. A single pass cross flow plate and fin heat exchanger configuration was chosen based on optimizing heat exchanger efficiency and compactness. The heat exchanger core configuration is shown schematically in Figure 4. A "wavy fin" or herringbone arrangement was selected to provide a greater surface area and better heat transfer performance. The surface geometry parameters for this type of surface are used to predict the pressure drop and heat transfer characteristics of each side of the heat exchanger.

To properly size the heat exchanger, an initial gas flow per unit area (mass velocity) is assumed for the air and gas sides of the heat exchanger. The heat exchanger NTU is derived from the calculated heat exchanger effectiveness and capacity ratio based on a correlation from [7]. The spreadsheet solver routine is used in the heat exchanger worksheet to iterate on the mass velocities until the heat transfer and core pressure drop requirements are met and convergence is achieved on both sides of the heat exchanger. The heat exchanger core mass is calculated based on an assumed solidity and the total heat exchanger mass is estimated based on approximations of the housing, header and nozzle masses.

The assumptions made in the heat exchanger design and mass estimate are summarized in Table 2.

Table 2 - Summary of assumptions used for the compact heat exchanger design and mass estimate

Heat Transfer Surface*

Heat Exchanger Material

Plate Thickness

Housing Thickness

Heat exchanger core solidity

Nozzle Weight

* Geometry obtained from Stewart Warner South Wind Corporation. However, friction and heat transfer data for this surface was not available, so Surface $11.44-3 / 8 \mathrm{w}$ provided in reference [6] was used for frictional and heat transfer data, since they have similar flow geometry.

** Surface nomenclature adopted from reference [6] where 20$3 / 8$ w infers 20 fins-per-inch with one complete wave every $3 / 8$ inch..

\section{Fuel Reformer}

The purpose of the catalytic partial oxidation (CPOX) fuel reformer is to reform the liquid jet fuel using auxiliary air and steam to provide hydrogen gas to the solid oxide fuel cell. A fuel injector combines and mixes the liquid jet fuel, steam and heated air and the reformer catalyzes the mixture to deliver the hydrogen gas to the fuel cell.
The fuel reformer design worksheet calculates the required reactor bed volume based on an assumed gas hourly space velocity of 50,000 hr ${ }^{-1}$ (recommended for a CPOX reformer). The overall length and diameter are determined based on an assumed reactor $\mathrm{L} / \mathrm{D}$ ratio of 2 . The injector, mixing and discharge length are assumed to be equal to one reactor bed diameter. The CPOX fuel reformer geometry is depicted in Figure 5.

With the reactor size determined, a secondary worksheet provides for a preliminary design of the reformer containment vessel. The containment vessel is sized to minimize heat loss from the reactor while maintaining low operating stresses in the containment vessel. In order to minimize heat losses from the reactor bed, internal and external insulation is used around the containment vessel. A one-dimensional radial heat transfer analysis is performed in the secondary worksheet to examine heat losses and estimate maximum metal temperatures. An internal heat transfer coefficient of the reformate gas is calculated based on the total flow through the reactor bed. Assumptions are made for internal insulation thickness, pipe wall thickness and external insulation thickness. An external heat transfer coefficient for the air surrounding the outer insulation is also approximated. Based on this information, an iterative procedure is used to determine all interface temperatures.

After the heat transfer analysis is completed, a stress calculation is performed to insure that the maximum allowable stresses are not exceeded based on the maximum operating temperature and pressure. The stress calculation assumes that the containment vessel is constructed from Inconel 625 material. The required vessel wall thickness is calculated to minimize mass while still providing acceptable margins of safety on stress. Table 3 summarizes the assumptions made in the fuel reformer design and mass estimate.

Table 3 - Summary of assumptions used for the fuel reformer design and mass estimate
Reactor Bed L/D Ratio

Internal Insulation Thickness

Minimum Containment Vessel

Wall Thickness

External Insulation Thickness

Injector Length

Injector Mixing Length

Reactor Exit Distance

Internal/ External Insulation

Reaction Vessel Material

External Ambient Temperature
2

Minimum to maintain a metal temperature of $540^{\circ} \mathrm{C}$.

$0.08 \mathrm{~cm}$

$1.3 \mathrm{~cm}$

One Reactor Bed Diameter

One Reactor Bed Diameter

One Reactor Bed Diameter

Alumina Silica Ceramic

Inconel 625

$425^{\circ} \mathrm{C}$

\section{Steam Generator}

The steam generator extracts heat from the combustion gases to vaporize water. The steam is routed to the fuel reformer injector, where it is mixed with fuel and heated air before entering the reformer catalyst bed. The combustion gas exits the steam generator and is routed to the radial inflow turbine. The steam generator worksheet utilizes the specified water, steam and exhaust inlet and discharge flow rate, temperature and pressure data and gas property data for the performance and mass estimate. Average water properties are calculated based on polynomial curve fit equations as a 
function of temperature that are incorporated into the spreadsheet.

A detailed heat transfer analysis is set up based on methods described in [8] to model the steam generator. A steam generator with water flow through the tubes is designed as a multi-pass steam generator in a counter flow arrangement. This is a continuous tube heat exchanger in which preheating, evaporation and superheating of the feed water take place consecutively. For the analysis, the water tubes are split into three sections. The preheater section is the portion of the tubing where the water is heated to its saturation temperature at the specified operating pressure. The evaporator section is the area where the water is vaporized into steam. The superheater section is the area where the steam is heated above its saturation temperature to the specified outlet temperature.

Average gas and water properties are evaluated for each section of the tubing. The heating requirements are determined and an NTU-effectiveness method is used to calculate the internal heat transfer coefficient of each section. The overall heat transfer coefficient is calculated based on the internal heat transfer coefficient of the water or steam, the external heat transfer coefficient of the combustion exhaust gas and the thermal conductivity of the tube. The overall heat transfer coefficient is used to predict a required tube length. Design iterations are then performed by varying the tube length until all heat transfer requirements are met and the calculated pressure drop on the exhaust gas side meets the specified exhaust gas pressure drop.

The multiple tube pass steam generator configuration is shown in Figure 6. The mass of the tubes is calculated and the external shell mass is estimated as a function of the tube mass. The assumptions made in the steam generator design and mass estimate are summarized in Table 4.

Table 4 - Summary of assumptions used for the steam generator design and weight estimate

Water/Steam Tube Material

Water/Steam Tube Size

Water/Steam Tube Wall Thickness

Tube Passes in the Longitudinal

Direction

Tube Spacing in the Longitudinal

Direction

Exit Steam Velocity

Steam Generator Housing Mass

(from [5])

Stainless Steel
$6.35 \mathrm{~cm} \mathrm{OD}$
$0.071 \mathrm{~cm}$
8
$4 *$ Tube OD
$50 \mathrm{~m} / \mathrm{sec}$
$1.85 *$ Mass of
Tubing

\section{Fuel and Water Pumps}

An investigation into commercially available pumps for the required operating ranges was made. Small, commercial pumps were found that cover the required fuel and water flow rate range with sufficient margin. Since the mass of the fuel and water pumps relative to the entire system mass is very small $(<0.3 \%)$, the fuel and water pump mass was considered constant for this investigation. Any minor changes to the fuel or water pump flow rate requirements should not result in a mass increase for these components.

\section{Radial Inflow Turbine}

The radial inflow turbine inlet in the AFCPS system directs combustor exhaust from downstream of the steam generator and extracts energy and discharges the exhaust gases to ambient (out the rear of the tail cone). It is assumed that the turbine discharge is through a nozzle to maintain a relatively low expansion ratio. The turbine expansion ratio is specified in the system analysis and is kept at values less than six to maintain low blade root stresses. The turbine worksheet utilizes the system inlet and discharge flow rate, temperature and pressure data and also the rotational speed as calculated in the compressor worksheet, since the compressor and turbine will be on the same shaft. The exit velocity diagram for the radial inflow turbine is shown in Figure 7. A preliminary radial inflow turbine rotor design is completed based on a detailed design method described in [4].

From the design method, the turbine rotor inlet diameter, exit shroud diameter and exit hub diameter is calculated. To obtain the meridional blade shape, the shroud shape is assumed to be $1 / 4$ of a circle and the hub shape is assumed to be $1 / 4$ of an ellipse. The turbine rotor mass is determined by calculating incremental volumes of the hub and blades based on the volume of a frustum of a cone. A blade solidity of $20 \%$ is assumed to estimate the amount of metal in the blade area. The total rotor mass is calculated based on the density of stainless steel and the volume estimate. The turbine inlet and housing mass estimate is based on a method described in [5]. Table 5 summarizes the assumptions made in the radial inflow turbine design and mass estimate.

Table 5 - Summary of assumptions used for the radial inflow turbine design and mass estimate

$\begin{array}{lc}\text { Rotor Blade Inlet Flow Angle, } \beta_{1} & 0^{\circ} \\ \text { Nozzle Exit Flow Angle, } \alpha_{\mathrm{C} 1} & 70^{\circ} \\ \text { Number of Rotor Blades, } \mathrm{Z} & 13 \\ \text { Rotor Polytropic Efficiency, } \eta_{\mathrm{P}, \mathrm{e}} & 0.85 \\ \text { Hub/Shroud Diameter Ratio at the } & \\ \text { Exducer Exit, } \Delta & 0.35 \\ \text { Hub Thickness Behind Blades } & 0.19 \mathrm{~cm} \\ \text { Shroud Shape } & 1 / 4 \text { of a circle } \\ \text { Hub Shape } & 1 / 4 \text { of an ellipse } \\ \text { Blade Solidity } & 0.20\end{array}$

\section{Solid Oxide Fuel Cell}

The anode inlet side of the solid oxide fuel cell collects fuel reformer products that include hydrogen, methane, nitrogen, water vapor, carbon monoxide and carbon dioxide. The cathode inlet side of the fuel cell collects air from the compressor that has been heated after passing through the heat exchanger. These gases are electrochemically reacted within the fuel cell to produce electrical power. The anode discharge side releases the electrochemical reaction products that include water vapor, carbon dioxide, nitrogen and the remaining hydrogen, carbon monoxide, and methane. The cathode discharge side releases water vapor, nitrogen as well as unused oxygen. A companion paper [2] details the performance model used to simulate the fuel cell performance. The performance model uses input settings (Area Specific Resistance $=0.4 \mathrm{ohm}$ $\mathrm{cm}^{2}$, Fuel Utilization $=0.85$, Cell Voltage $\left.=0.75 \mathrm{~V}\right)$ to output performance and required SOFC active area. Several assumptions are required to convert the active area requirement into stack volume and mass estimates. A schematic of the assumed cell dimensions is shown in Figure 8 while the stack geometry is described in Figure 9. Table 6 summarizes the assumptions made for the dimensions and materials for the fuel 
cell stack sizing and mass estimate.

Table 6 - Summary of assumptions used for the fuel cell stack sizing and mass estimate.

$\begin{array}{lcl}\text { anode effective density } & 5.32 & \mathrm{~g} / \mathrm{cm}^{3} \\ \text { anode thickness } & 430 & \text { microns } \\ \text { electrolyte effective density } & 6 & \mathrm{~g} / \mathrm{cm}^{3} \\ \text { electrolyte thickness } & 3 & \text { microns } \\ \text { cathode effective density } & 4.41 & \mathrm{~g} / \mathrm{cm}^{3} \\ \text { cathode thickness } & 40 & \text { microns } \\ \text { interconnect effective density } & 4.58 & \mathrm{~g} / \mathrm{cm}^{3} \\ \text { interconnect thickness } & 2200 & \mathrm{microns} \\ \text { cell total area } & 400 & \mathrm{~cm}^{2} \\ \text { cell active area } & 324 & \mathrm{~cm}^{3} \\ \text { repeating unit thickness } & 2673 & \mathrm{microns} \\ \text { repeating unit mass } & 502 & \mathrm{~g} \\ \text { compression rod material density } & 8.9 & \mathrm{~g} / \mathrm{cm}^{3} \\ \text { compression rod diameter } & 7500 & \mathrm{microns} \\ \text { endplate material density } & 8.9 & \mathrm{~g} / \mathrm{cm}^{3} \\ \text { endplate thickness } & 5000 & \mathrm{microns}\end{array}$

The dimensions stated above represent an effort to extrapolate from current state-of-the-art to a timeframe ten years out (2015). For reference to current technology levels, the interested reader should refer to [9] and [10]. The material properties represent current solid oxide fuel cell technology. For the porous materials and the metallic interconnect with gas channels, an effective density has been given which accounts for the open volume. The baseline SOFC stacks are twelve in number, with 172 cells per stack.

The worksheet estimates the mass of the fuel cell stack, tie rods and endplates but does not include any portion of the housing or inlet and discharge manifolds. The housing mass is estimated based on initial 3D modeling and is added to the spreadsheet thereafter. Nevertheless, the mass of the stack dominates the systems mass estimate, and the interconnect mass is particularly significant.

\section{Combustor}

The combustor combines unburned fuel (hydrogen, methane, carbon monoxide and carbon dioxide) from the anode discharge side of the fuel cell and a portion of the air from the cathode discharge side of the fuel cell and provides a means to combust these gases further to raise the exhaust gas temperature and increase the efficiency of the hybrid system.

It was determined that if a large portion of the air was bypassed by the combustor, a tubular combustor was suitable for this application. The tubular combustor was sized and designed based on methods described in [11]. Two different sizing methods are examined and the largest (most conservative) combustor size is selected. Assumptions for the liner and casing thickness are made to provide an approximate combustor mass. It is anticipated that further investigations into the combustor sizing can incorporate a chemical kinetic calculation to determine a more accurate size for the combustor, since it is believed that the combustor is conservatively oversized based on the effect that the high inlet temperature has on empirical correlations. Future designs may end up incorporating a catalytic combustor, although further off-design performance requirements will need to be considered.

\section{Starter/Generator}

The mass of the starter/generator is conservatively estimated to be constant for this configuration based on starter/generator masses that are listed in [5] for systems in the size range being investigated.

\section{Hot Box Assemblies}

The purpose of the hot box assemblies is to provide insulation containment for all hot components. Each hot box will be packed with insulation to minimize equipment heat losses. . For the packaging investigation, the fuel cell stacks and combustor were packaged within one hot box and the heat exchanger, steam generator and fuel reformer were packaged within the other hot box. These components were packaged within close proximity to each other so that they could be surrounded by integral enclosures. The mass of each hot box is calculated based on the surface area calculated in the 3D model and an assumed thickness and material density.

\section{Interconnecting Piping}

A separate worksheet is provided within the program to estimate the diameter and mass of the interconnecting piping in the system. This worksheet uses system inputs of flow rate, temperature, density and dynamic viscosity for each interconnecting line. The diameter of each line is initially approximated based on assuming a velocity of $100 \mathrm{ft} / \mathrm{sec}$ for gases and $10 \mathrm{ft} / \mathrm{sec}$ for liquids (and then potentially changed slightly based on practical considerations from the $3 \mathrm{D}$ model). The mass of each line is calculated based on an assumed pipe or tube wall thickness, as well as the approximate length of line that is estimated from the 3D model. Based on the calculated Reynolds number in the line, a friction factor is computed and a pressure drop per foot of line is tabulated.

\section{Individual Component Dimensions}

A separate summary worksheet is generated that tabulates dimensional data of all major components. This dimensional summary worksheet can then be supplied to a designer for three dimensional modeling.

\section{Total System Mass Summary}

The final worksheet in the spreadsheet program provides a total solid oxide fuel system mass summary based on an aircraft APU application. Each calculated component mass is summarized and the percent of its mass relative to the entire system mass is tabulated and plotted to provide an aid to determine which components have a significant impact on the total system mass.

\section{Three Dimensional Solid Model Development}

Based on the individual component dimensions calculated in the spreadsheet program, a 3D solid model of the system was developed and is shown within a B777 tail section. Initial packaging studies have shown that the system can be packaged to fit within the tail section.

Since the fuel cell stacks were presumed to be the heaviest items, it was decided to locate them near the tail section bulkhead to reduce the loads on the support structure. The compressor, fuel pump and water pump were also located near 
the bulkhead, since it is presumed that the penetrations for the air, fuel and water lines would occur through the bulkhead. A 3D simulation of the system within the B777 tail section is presented in Figure 2.

\section{Component Trade Studies}

The code has been constructed to allow for variable component sizing required for system trade studies. Parametric trade studies were performed independently for each major component in the system, demonstrating how each component mass varies as a function of operating condition.

Figure 11 shows centrifugal compressor mass as a function of pressure ratio. Figure 12 presents compressor mass as a function of mass flow rate. It is noted that for these spreadsheet analyses, the compressor non-dimensional specific speed is held constant to maintain optimum design point efficiency. The program calculates a different rotational speed for each pressure ratio case. This results in decreasing compressor mass with increasing pressure ratio, since the increased rotational speed produces a smaller compressor rotor requirement.

Figure 13 shows the effect of pressure drop across each side of the heat exchanger on the heat exchanger mass. These calculations are performed at several mass flow rates through each side of the heat exchanger to also show the effect of mass flow rate on heat exchanger mass. It is observed that the heat exchanger mass and volume decrease as the allowable pressure drop increases. The effect of decreased heat exchanger mass can be compared to the resultant increase in compressor size to overcome the increased pressure loss.

Figure 14 shows the effect of feed flow rate on fuel reformer mass. This calculation was performed at several different operating pressures. The reformer spreadsheet calculates the required wall thickness based on operating pressure and temperature as well as material properties, assuming an Inconel 625 housing. However, if the required wall thickness falls below a minimum recommended manufacturing limit of $0.08 \mathrm{~cm}$, the calculation defaults to the minimum wall thickness. For this study, in the pressure range of interest $(100-400 \mathrm{kPa})$, the calculated wall thickness always defaulted to the minimum practical limit, since the actual required wall thickness was calculated to be less. Therefore, the effect of pressure on the fuel reformer mass is negligible for this study. For this investigation, the steam and oxygen to carbon ratio was held constant and the reactor bed L/D ratio was held at two. The figure shows that the fuel reformer mass increases with mass flow rate, which is to be expected, since a larger catalyst volume would be required.

Figure 15 shows the effect of gas side pressure drop on the steam generator mass. This calculation was performed at several different mass flow rates, with the ratio of exhaust gas mass flow rate to water mass flow rate held constant. As with the heat exchanger, a larger allowable gas side pressure drop results in a smaller, more lightweight steam generator.

The effect of expansion ratio on turbine mass is presented in Figure 16. These calculations are performed at constant mass flow rate, inlet temperature, inlet pressure and various rotational speeds (since the spreadsheet program sets turbine speed based on calculated compressor speed). As expected, it is observed that as turbine expansion ratio increases, the total turbine mass increases.

A trade study on the mass of the solid oxide fuel cell stack was performed by varying current density and voltage to obtain the required power. The effect on the resultant mass of the fuel cell stack is depicted in Figure 17. This calculation was carried out at a constant area specific resistance of $0.4 \mathrm{ohm}-\mathrm{cm}^{2}$ and constant electrode gas flows, pressures and temperatures.

The effect of mass flow rate on combustor mass is presented in Figure 18. The calculations are carried out at several inlet pressures. Inlet temperature is held constant, as well as the fuel/air ratio. The combustor mass increases almost linearly with mass flow rate at a given pressure, but the effect of operating at higher combustor pressures has a more significant effect on combustor mass.

\section{System Trade Studies}

The entire spreadsheet program was executed for two different APU operating conditions to examine the effects of system mass when the system is designed for cruise or sea level operation. A typical output summary of the component weight breakdown for the sea level and cruise design cases is shown in Tables 7 and 8. A pie chart showing the relative weights of the components when the system is designed for sea level conditions is shown in Figure 19. A pie chart showing the relative weights of the components when the system is designed for aircraft conditions is shown in Figure 20. For the cruise and sea level design studies, the hot box and interconnecting piping masses listed are the same since they are based on the packaging design presented in Figure 2 (cruise design case) and 3D packaging was not performed for the sea level case.

Table 7 - Spreadsheet Output Summary - Sea Level Case

\begin{tabular}{|c|c|c|c|}
\hline $\begin{array}{l}\text { Component } \\
\text { Description }\end{array}$ & $\begin{array}{c}\text { Sub- } \\
\text { Component } \\
\text { M ass (kg) }\end{array}$ & $\begin{array}{c}\text { Total } \\
\text { Component } \\
\text { M ass (kg) }\end{array}$ & $\begin{array}{l}\% \text { of } \\
\text { Total } \\
\text { M ass }\end{array}$ \\
\hline Fuel Pump/M otor & & 1.6 & 0.08 \\
\hline Water P ump/M otor & & 1.6 & 0.08 \\
\hline Compressor & & 12.7 & 0.66 \\
\hline Rotor & 4.2 & & \\
\hline Diffuser Scroll & 1.4 & & \\
\hline Housing & 7.2 & & \\
\hline Turbine & & 12.1 & 0.63 \\
\hline Rotor & 3.9 & & \\
\hline Inlet Scroll & 1.3 & & \\
\hline Housing & 6.9 & & \\
\hline Starter/Generator & & 6.8 & 0.36 \\
\hline A ir/Exhaust Heat Exchanger & & 49.7 & 2.60 \\
\hline Headers & 8.3 & & \\
\hline Core & 40.9 & & \\
\hline Nozzle & 0.4 & & \\
\hline Solid Oxide Fuel Cell Stack & & 1595.6 & 83.42 \\
\hline A uto Thermal Reformer & & 16.2 & 0.84 \\
\hline Catalyst/Reactor Bed & 5.5 & & \\
\hline Internal Insulation (Ceramic) & 3.8 & & \\
\hline Injecto r/M ixer/Housing & 4.5 & & \\
\hline External Insulation (Ceramic) & 2.3 & & \\
\hline Combustor & & 22.4 & 1.17 \\
\hline Hot Boxes & & 94.8 & 4.96 \\
\hline Steam Gen/Heat Exch/Reform & 37.4 & & \\
\hline Fuel Cell Stacks/Combustor & 57.4 & & \\
\hline Steam Generator & & 5.3 & 0.28 \\
\hline Tubes & 1.9 & & \\
\hline $\begin{array}{l}\text { Housing/M anifold } \\
\text { Interconnect } \mathrm{P} \text { iping/Tubing }\end{array}$ & 3.4 & 93.9 & 4.91 \\
\hline TotalSystem Mass, kg & & 1912.7 & 100 \\
\hline
\end{tabular}


Table 8 - Spreadsheet Output Summary - Cruise Case

\begin{tabular}{|c|c|c|c|}
\hline $\begin{array}{l}\text { Component } \\
\text { Description }\end{array}$ & $\begin{array}{c}\text { Sub- } \\
\text { Component } \\
\text { Mass (kg) }\end{array}$ & $\begin{array}{c}\text { Total } \\
\text { Component } \\
\text { Mass }(\mathrm{kg})\end{array}$ & $\begin{array}{l}\% \text { of } \\
\text { Total } \\
\text { Mass }\end{array}$ \\
\hline Fuel Pump/Motor & & 1.6 & 0.11 \\
\hline Water Pump/Motor & & 1.6 & 0.11 \\
\hline Compressor & & 11.8 & 0.84 \\
\hline Rotor & 3.7 & & \\
\hline Diffuser Scroll & 1.3 & & \\
\hline Housing & 6.8 & & \\
\hline Turbine & & 18.8 & 1.35 \\
\hline Rotor & 7.3 & & \\
\hline Inlet Scroll & 2.1 & & \\
\hline Housing & 9.4 & & \\
\hline Starter/Generator & & 6.8 & 0.49 \\
\hline Air/Exhaust Heat Exchanger & & 41.1 & 2.94 \\
\hline Headers & 7.7 & & \\
\hline Core & 33.0 & & \\
\hline Nozzle & 0.4 & & \\
\hline Solid Oxide Fuel Cell Stack & & 1085.0 & 77.71 \\
\hline Auto Thermal Reformer & & 12.2 & 0.87 \\
\hline Catalyst/Reactor Bed & 3.8 & & \\
\hline Internal Insulation (Ceramic) & 3.0 & & \\
\hline Injector/Mixer/Housing & 3.6 & & \\
\hline External Insulation (Ceramic) & 1.8 & & \\
\hline Combustor & & 24.6 & 1.76 \\
\hline Hot Boxes & & 94.8 & 6.79 \\
\hline Steam Gen/Heat Exch/Reform & 37.4 & & \\
\hline Fuel Cell Stacks/Combustor & 57.4 & & \\
\hline Steam Generator & & 4.0 & 0.29 \\
\hline Tubes & 1.4 & & \\
\hline Housing/Manifold & 2.6 & & \\
\hline Interconnect Piping/Tubing & & 93.9 & 6.73 \\
\hline Total System Mass, kg & & 1396.2 & 100 \\
\hline
\end{tabular}

\section{SUMMARY AND CONCLUSIONS}

Parametric mass and volume models have been developed to provide preliminary mass and performance estimates of the various components that are required in an Aircraft Fuel Cell Power System for an aircraft auxiliary power unit. The program has been designed to read in system model data and provide preliminary component mass and performance estimates so that the research team can quickly ascertain the mass impact of fuel cell hybrid system modifications. This linking of the system model output to the spreadsheet program should allow for rapid parametric trade studies to be performed to optimize the development of the hybrid aircraft fuel cell power system. Component trade studies using the program have been performed and are discussed. Two system examples using the program to analyze a solid oxide fuel cell/gas turbine hybrid system are presented. Further system trade studies using the program have been performed on the solid oxide fuel cell/gas turbine hybrid system and are discussed in detail in [2].

\section{REFERENCES}

1. Daggett, D., Freeh, J.E., Balan, C., Birmingham, D., 2003 Fuel Cell Seminar Abstracts, pp. 1008-1011, Miami Beach, FL (2003).

2. Steffen, C.J. Jr., Freeh, J.E., Larosiliere, L.M., "Hybrid Solid Oxide Fuel Cell/ Gas Turbine technology for Auxiliary Aerospace Power", Abstract Submitted to ASME IGTI Conference, Reno, NV (2005).

3. Leong, P., Severns, C., Dummeyer D., Hadaller, O., Breit, J. and Space, D., 2003, "Hybrid Fuel Cell Auxiliary Power Unit (FCAPU) Aircraft and FCAPU Requirements (DRAFT)", The Boeing Company.

4. Wilson, D.G. and Korakianitis, T., 1984, The Design of High Efficiency Turbomachinery and Gas Turbines, $2^{\text {nd }}$ Edition, Prentice Hall, Inc., Upper Saddle River, New Jersey.

5. Hale, P. L., 1982, "A Method to Estimate Weight and Dimensions of Small Aircraft Propulsion Gas Turbine Engines". (Prepared for the NASA/Lewis Research Center, 1982, Contract NASA-23037).

6. Kays, W.M. and London, A.L., 1988, Compact Heat Exchangers, $3^{\text {rd }}$ Edition, Krieger Publishing Company, Malabar, Florida.

7. Holman, J. P., 1981, Heat Transfer, $5^{\text {th }}$ Edition, McGraw Hill, New York.

8. Ganaparthy, V., 2003, Industrial Boilers and Heat Recovery Steam Generators: Design, Applications and Calculations, Marcel Dekker, Inc., New York.

9. Assessment of Solid Oxide Fuel Cell Technology: Comparisons of Alternative Design Approaches, EPRIsolutions, Palo Alto, CA: 2002. 1003966

10. Handbook of Fuel Cells: Fundamentals, Technology, Applications, 4-Volume Set, Vielstich, W., Lamm, A. and Gasteiger H., Editors, ISBN: 0-471-49926-9, May 2003.

11. Lefebvre, A. H., 1999, Gas Turbine Combustion, $2^{\text {nd }}$ Edition, Taylor and Francis, Ann Arbor, Michigan.

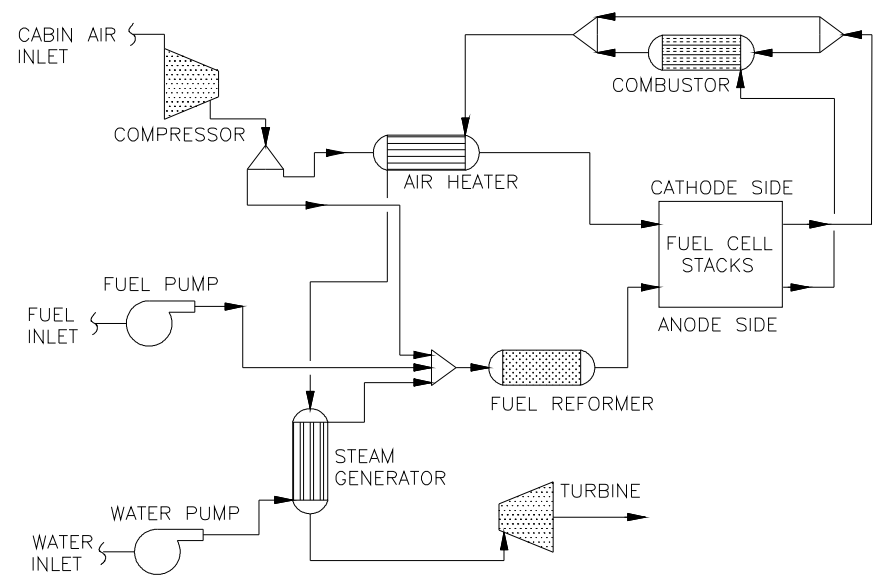

Figure 1 - SOFC Hybrid System Schematic 


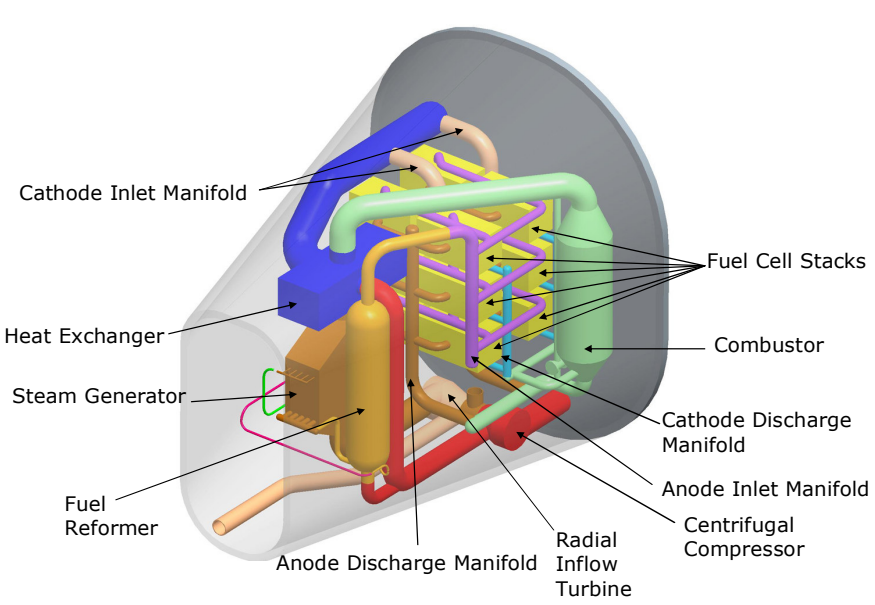

Figure 2 - Solid Oxide Fuel Cell Hybrid APU Packaging
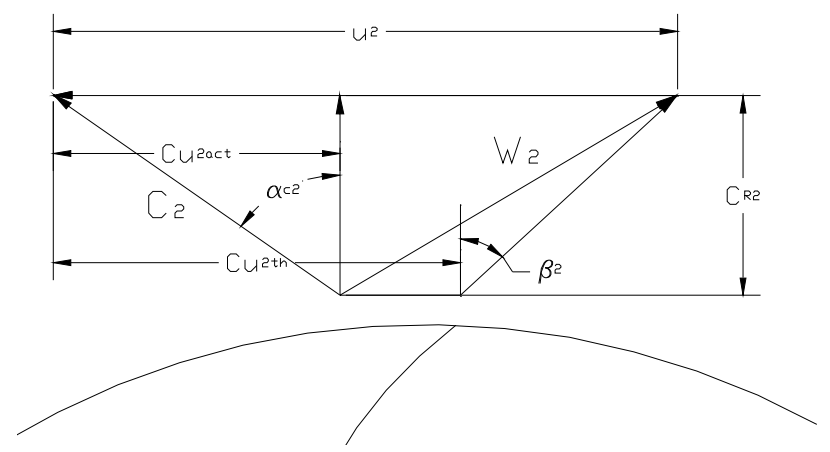

Figure 3 - Centrifugal Compressor Exit Velocity Diagram

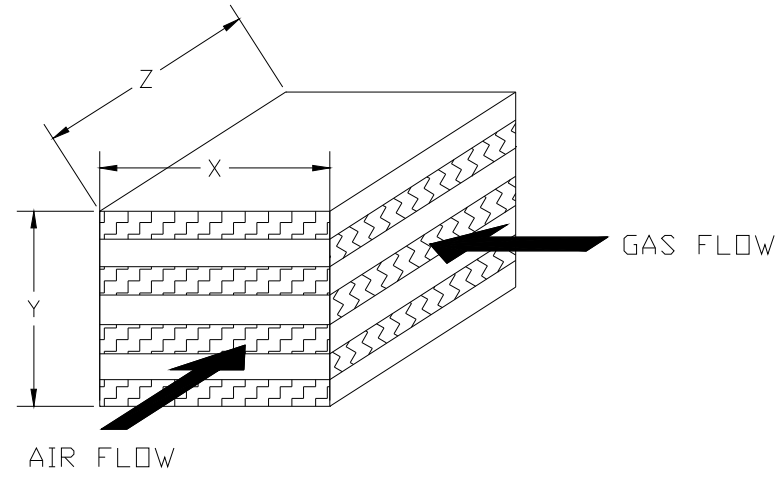

Figure 4 - Heat Exchanger Core Configuration

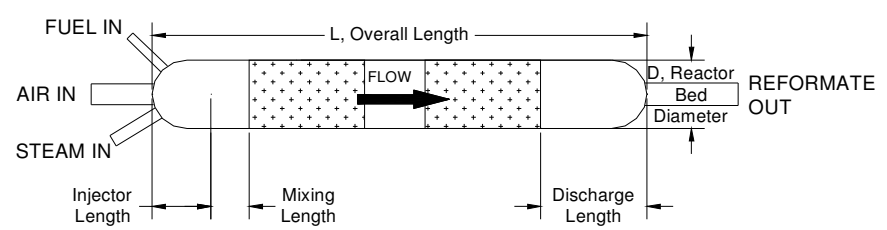

Figure 5 - Fuel Reformer Geometry

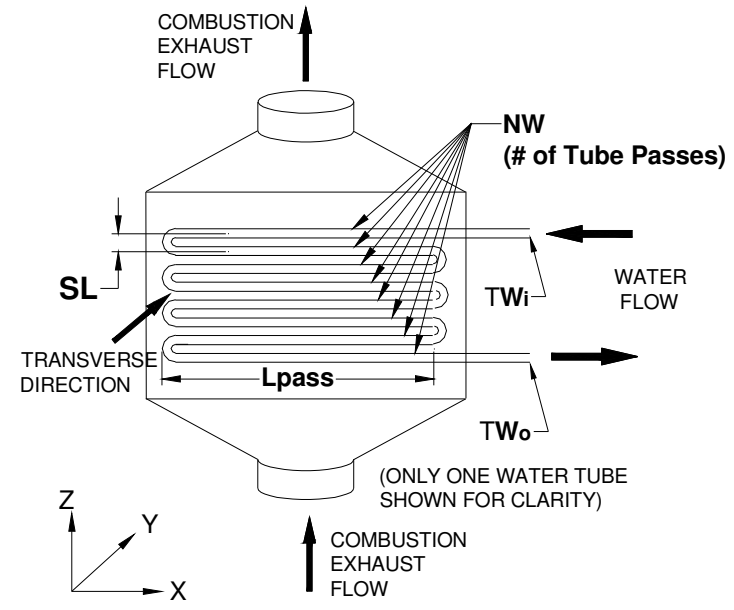

Figure 6 - Multi-Pass Steam Generator
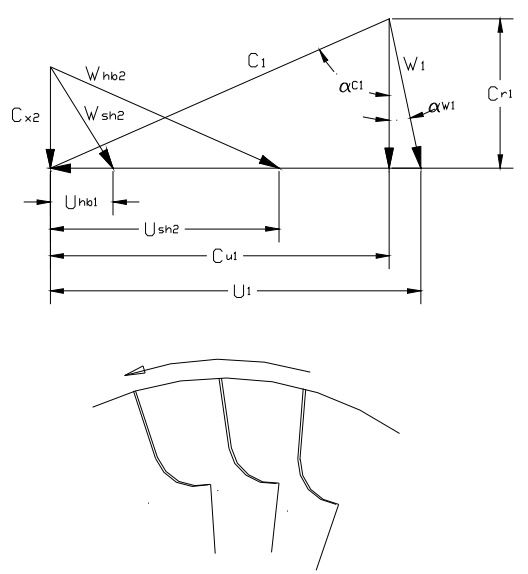

Figure 7 - Radial Inflow Turbine Exit Velocity Diagram

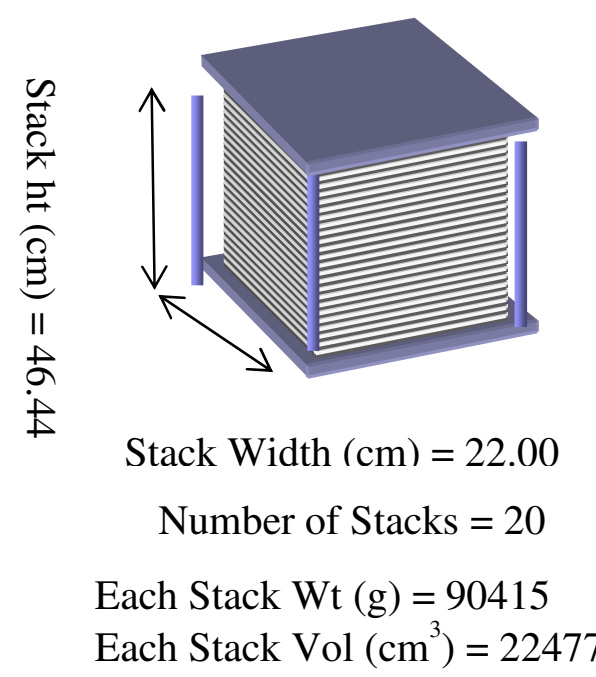

Figure 8 - Solid Oxide Fuel Cell Model Schematic, Assumed fuel cell dimensions 


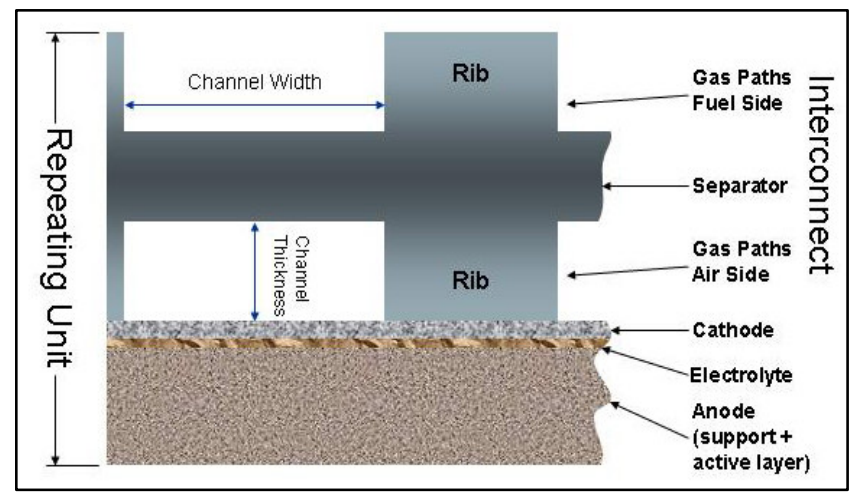

Figure 9 - Solid Oxide Fuel Cell Model, Anode Supported, Metallic Interconnect

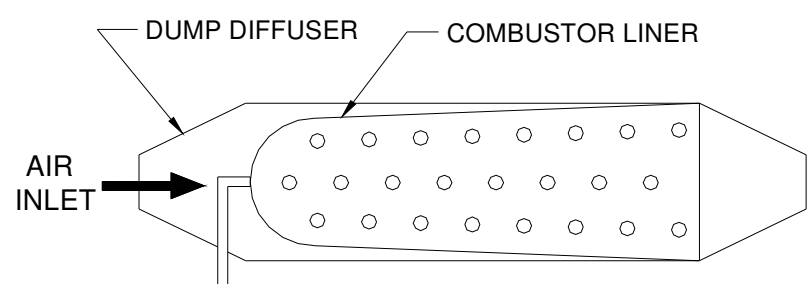

FUEL

INLET

Figure 10 - Tubular Combustor Configuration

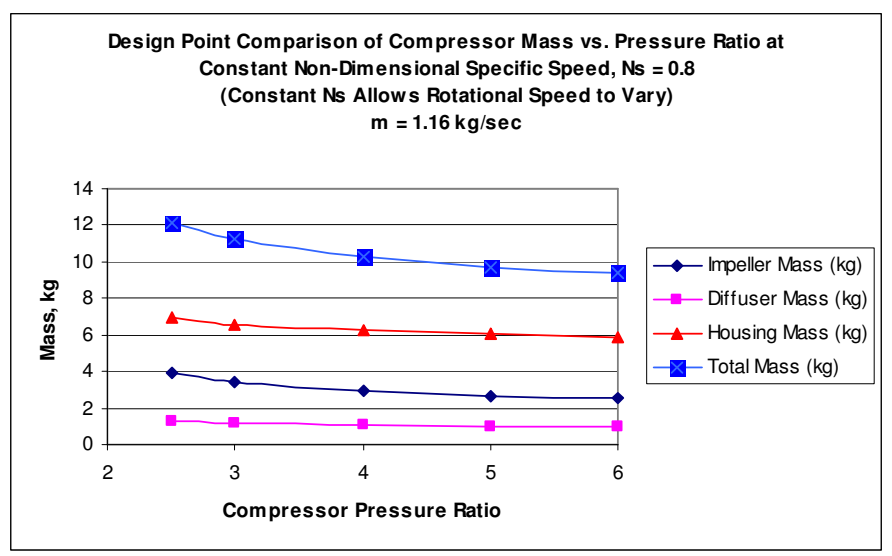

Figure 11 - Compressor Mass vs. Pressure Ratio
Design Point Comparison of Compressor Mass vs. Mass Flow Rate at Constant Non- Dimensional Specific Speed, Ns $=0.8$ (Constant Ns Allows Rotational Speed to Vary) Compressor Pressure Ratio $=3$

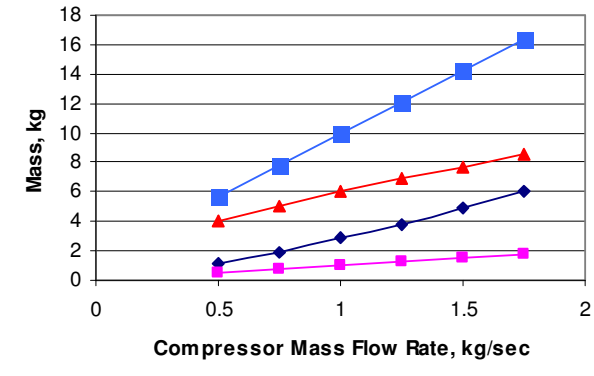

$\multimap$ Impeller Mass $(\mathrm{kg})$ - Diffuser Mass $(\mathrm{kg})$ $\_$Housing Mass $(\mathrm{kg})$ - Total Mass $(\mathrm{kg})$

Figure 12 - Compressor Mass vs. Mass Flow Rate

Design Point Comparison of Heat Exchanger Mass vs. Pressure Drop Baseline $(100 \%)$ Flow Rate $=1.096 \mathrm{~kg} / \mathrm{sec}$ (Air Side), $1.188 \mathrm{~kg} / \mathrm{sec}$ (Exhaust Side)

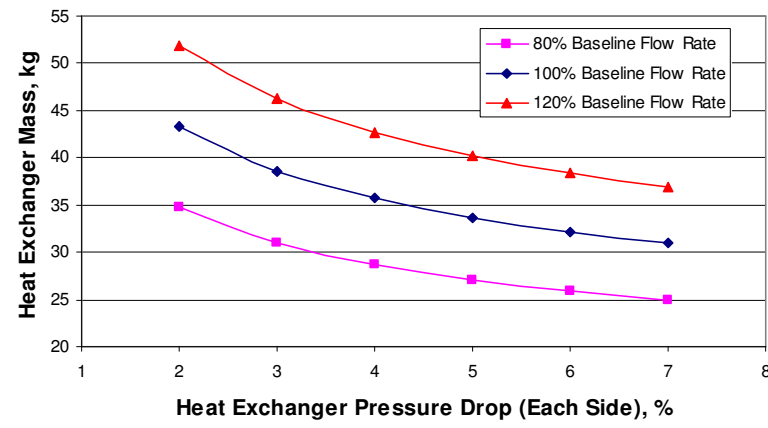

Figure 13 - Heat Exchanger Mass vs. Pressure Drop

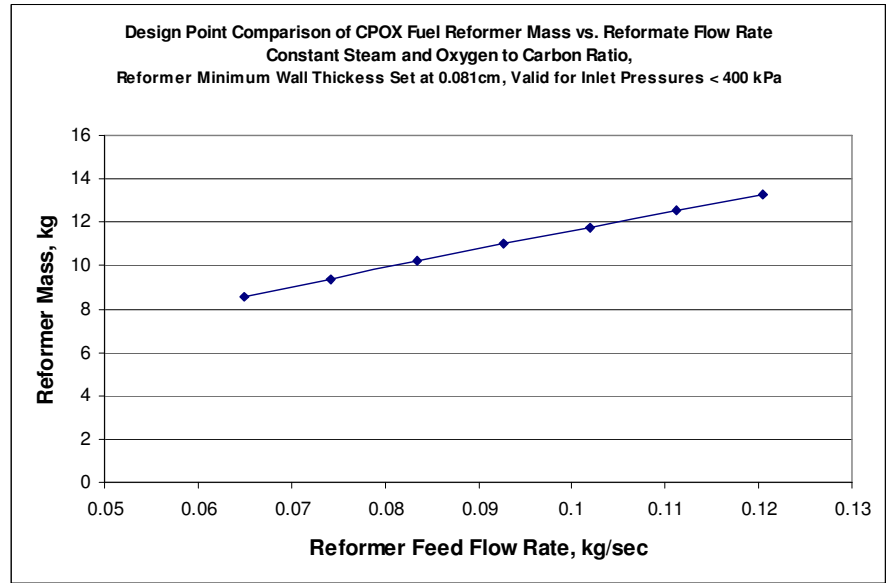

Figure 14 - Fuel Reformer Mass vs. Mass Flow Rate 


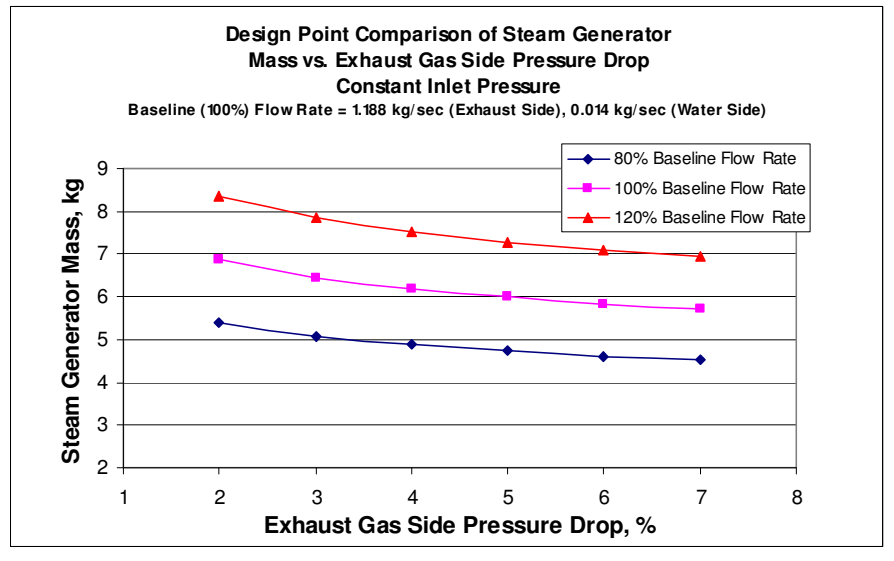

Figure 15 Steam Generator Mass vs. Exhaust Gas Side Pressure Drop

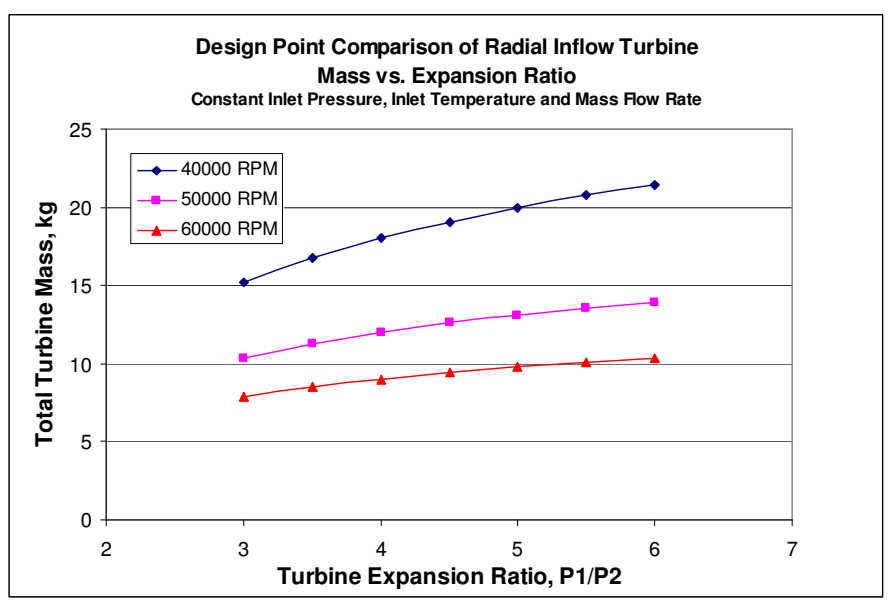

Figure 16 Radial Inflow Turbine Mass vs. Expansion Ratio

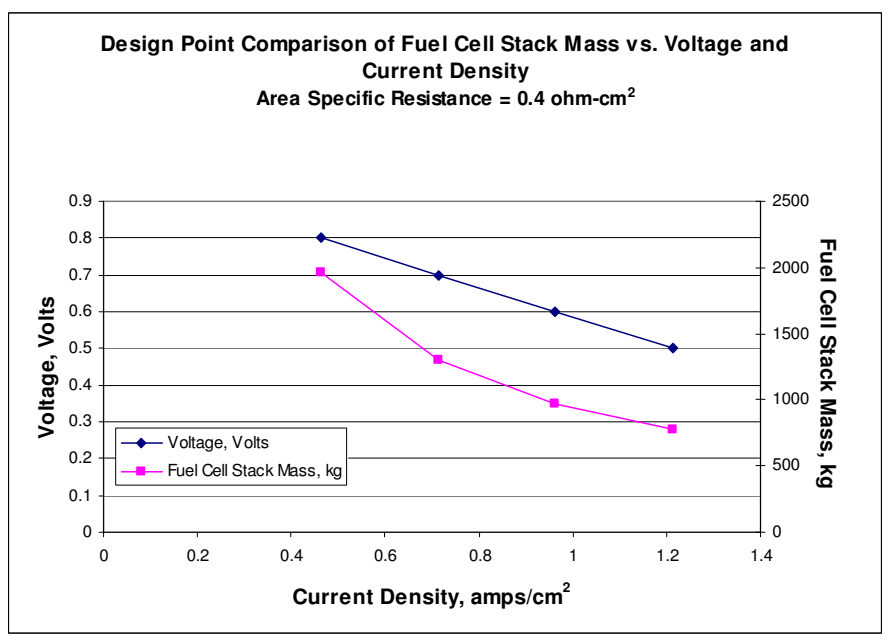

Figure 17 Solid Oxide Fuel Cell Stack Mass vs. Current Density and Stack Operating Voltage

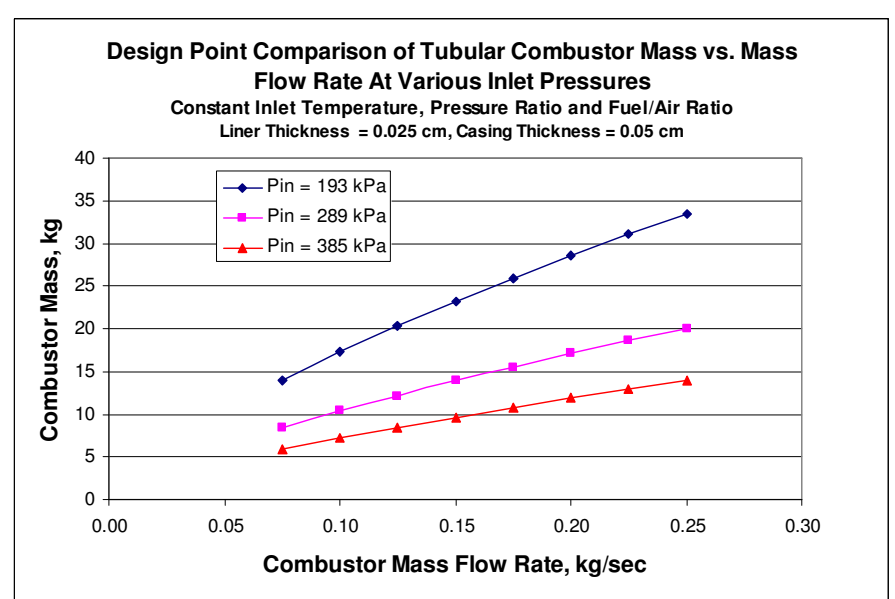

Figure 18 Combustor Mass vs. Operating Pressure
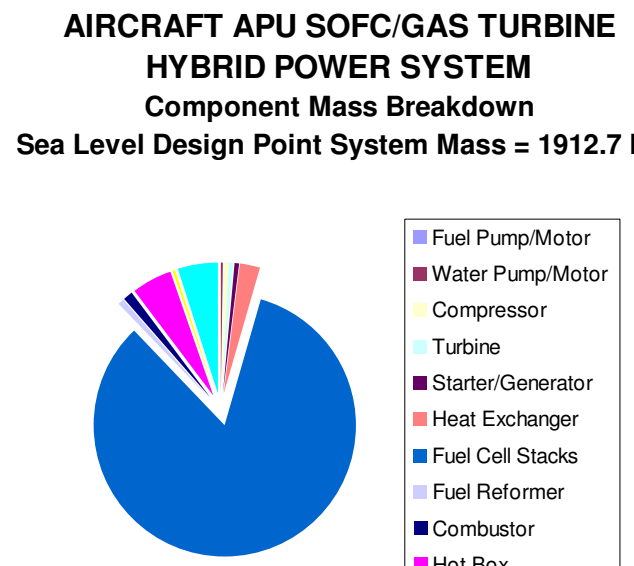

\begin{tabular}{|l|}
\hline Fuel Pump/Motor \\
Water Pump/Motor \\
Compressor \\
Turbine \\
- Starter/Generator \\
Heat Exchanger \\
- Fuel Cell Stacks \\
Fuel Reformer \\
Combustor \\
Hot Box \\
Steam Generator \\
Piping
\end{tabular}

Figure 19 Relative Masses of System Components - Sea Level Design Case Spreadsheet Summary Output

\section{AIRCRAFT APU SOFC/GAS TURBINE HYBRID POWER SYSTEM \\ Component Mass Breakdown \\ Cruise Design Point System Mass $=1396.2 \mathrm{~kg}$}

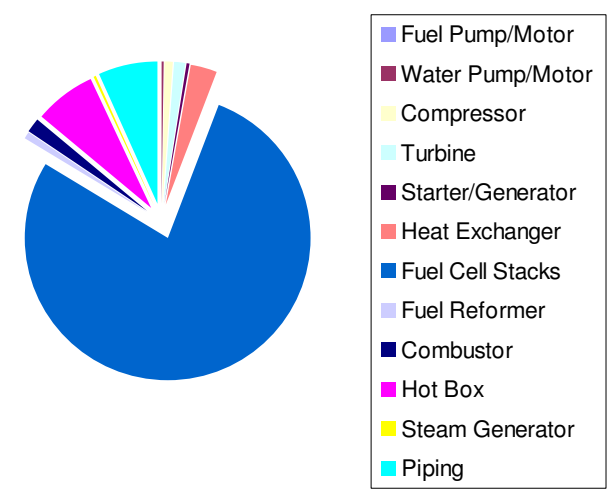

Figure 20 Relative Masses of System Components - Cruise Design Case Spreadsheet Summary Output 


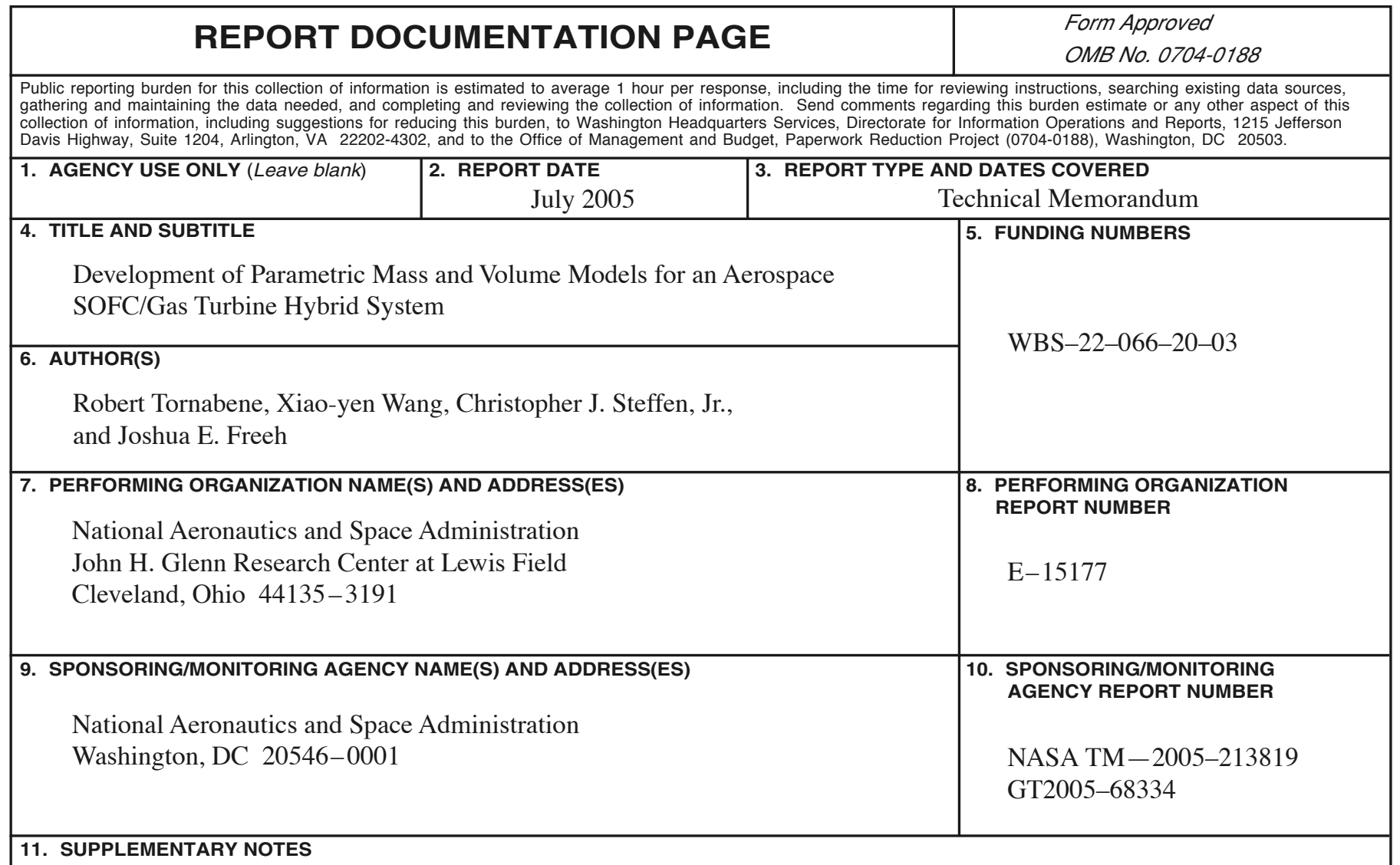

Prepared for the Turbo Expo 2005 sponsored by the American Society of Mechanical Engineers, Reno, Nevada, June 6-9, 2005. Responsible person, Robert Tornabene, organization code DEC, 216-433-3045.

\begin{tabular}{|l|l}
\hline 12a. DISTRIBUTION/AVAILABILITY STATEMENT & 12b. DISTRIBUTION CODE \\
Unclassified - Unlimited & \\
Subject Category: 07 & \\
Available electronically at http://gltrs.grc.nasa.gov & \\
This publication is available from the NASA Center for AeroSpace Information, 301-621-0390. &
\end{tabular}

\section{ABSTRACT (Maximum 200 words)}

In aerospace power systems, mass and volume are key considerations to produce a viable design. The utilization of fuel cells is being studied for a commercial aircraft electrical power unit. Based on preliminary analyses, a SOFC/gas turbine system may be a potential solution. This paper describes the parametric mass and volume models that are used to assess an aerospace hybrid system design. The design tool utilizes input from the thermodynamic system model and produces component sizing, performance, and mass estimates. The software is designed such that the thermodynamic model is linked to the mass and volume model to provide immediate feedback during the design process. It allows for automating an optimization process that accounts for mass and volume in its figure of merit. Each component in the system is modeled with a combination of theoretical and empirical approaches. A description of the assumptions and design analyses is presented.

\begin{tabular}{|c|c|c|}
\hline \multicolumn{3}{|c|}{$\begin{array}{l}\text { Solid oxide fuel cell (SOFC); Hybrid gas turbine system; Auxiliary power unit; } \\
\text { Systems analysis }\end{array}$} \\
\hline $\begin{array}{l}\text { 17. SECURITY CLASSIFICATION } \\
\text { OF REPORT }\end{array}$ & $\begin{array}{l}\text { 18. SECURITY CLASSIFICATION } \\
\text { OF THIS PAGE }\end{array}$ & $\begin{array}{l}\text { 19. SECURITY CLASSIFICATION } \\
\text { OF ABSTRACT }\end{array}$ \\
\hline Unclassified & Unclassified & Unclassified \\
\hline
\end{tabular}



